\title{
The application of U-isotopes to assess weathering in contrasted soil-water regime in Brazil
}

\author{
Vania Rosolen $^{\mathrm{a}}$, Guilherme Taitson Bueno ${ }^{\mathrm{b}}$, Daniel Marcos Bonotto ${ }^{\mathrm{a}, *}$ \\ a Departamento de Petrologia e Metalogenia, Universidade Estadual Paulista (UNESP), Câmpus de Rio Claro, Av. 24-A, No.1515, C.P. 178, CEP 13506-900 Rio Claro, \\ São Paulo, Brasil \\ b Instituto de Estudos Sócio-Ambientais, Universidade Federal de Goiás (UFG), Campus II, CEP 74001-970 Goiânia, Goiás, Brasil
}

\section{H I G H L I G H T S}

- Contrasted soil-water regime.

- U-isotopes disequilibrium in soil profiles.

- Adsorbents for uranium.

- Dating of soils horizons.

\section{A R T I C L E I N F O}

\section{Keywords:}

Uranium isotopes

Lateritic soil

Hydromorphy

Dating

Marilia formation

\begin{abstract}
A B S T R A C T
This paper presents the use of $U$-series radionuclides ${ }^{238} U$ and ${ }^{234} U$ to evaluate the biogeochemical disequilibrium in soil cover under a contrasted soil-water regime. The approach was applied in three profiles located in distinct topographical positions, from upslope ferralitic to downslope hydromorphic domain. The $\mathrm{U}$ fractionation data was obtained in the samples representing the saprolite and the superficial and subsuperficial soil horizons. The results showed a significant and positive correlation between $U$ and the Total Organic Carbon (TOC). Soil organic matter has accumulated in soil due to hydromorphy. There is no evidence of positive correlation between $\mathrm{U}$ and $\mathrm{Fe}$, as expected in lateritic soils. The advance of the hydromorphy on Ferralsol changes the weathering rates, and the ages of weathering are discussed as a function of the advance of waterlogged soil conditions from downslope. Also, the bioturbation could represent the other factor responsible to construct a more recent soil horizon.
\end{abstract}

\section{Introduction}

The evolution and age of soils can be determined using the U-isotopes ${ }^{238} \mathrm{U}$ and ${ }^{234} \mathrm{U}$ approach. The information generated by the method is valuable to determine the process presently active in profiles which control the chemical fluxes carried by rivers from continent (Chabaux et al., 2003). The two natural U-isotopes ${ }^{238} \mathrm{U}$ and ${ }^{235} \mathrm{U}$ are precursors of the natural mass number $4 n+2$ and $4 n+3$ decay series, respectively. The third natural $\mathrm{U}$-isotope, ${ }^{234} \mathrm{U}$, is radiogenic and generated in the ${ }^{238} \mathrm{U}$ decay chain according to the sequence: ${ }^{238} \mathrm{U}(4.46$ Ga, $\alpha) \rightarrow{ }^{234} \mathrm{Th}$ (24.1 days, $\beta$ ) $\left.\rightarrow{ }^{234} \mathrm{~Pa} \mathrm{(1.18} \mathrm{min,} \alpha\right) \rightarrow{ }^{234} \mathrm{U}$ (248 ka, $\alpha) \rightarrow \ldots{ }^{206} \mathrm{~Pb}$ (Cherdyntsev, 1971). The property of the nuclides to be fractionated during water-rock/soil interactions and to have radioactive periods of the same order of magnitude as the time constants of many weathering processes highlight the interest of $\mathrm{U}$-series nuclides as tracers and chronometers of weathering processes (Chabaux et al., 2006).

In a catena with contrasting soil-water regimes, differential geochemical transport take place in different time scales. The processes involving alteration, transportation, and authigenesis are induced by climatic changes and pedogenesis, which interact with the initial soil to form another with different structure and composition (Lucas and Chauvel, 1992). The result of the processes is a new soil consisting of organic and mineral products whose evolution is the biogeochemical rebalance.

The advance of aquic conditions from downslope to upslope at some geological time, transforms the physical-chemical characteristics of older lateritic soil profile located in well-drained position of the slope (Peterschimitt et al., 1996; Rosolen et al., 2002; Barbiero et al., 2010). Thus, two situations of weathering and time are involved in this soil

\footnotetext{
* Corresponding author.

E-mail address: danielbonotto@yahoo.com.br (D.M. Bonotto).
} 
landscape evolution: (1) the older profile representing a time sequence derived from weathering of parent material, and (2) the newer profile in which each horizon having been derived from the older material undergone to the advance of transformation front.

Since weathering fractionates $U$ nuclides and creates $U$ disequilibria in soil, the method has been successfully applied for studying and dating recent Quaternary phenomena (Chabaux et al., 2003). Despite the isotopic techniques be an important tool in pedological studies, the use of ${ }^{238} \mathrm{U}$ and ${ }^{234} \mathrm{U}$ for evaluating weathering processes occurring in horizons of soil profiles is still incipient compared to the large extension of the exposed soil covers in the tropical countries (e.g. Bonotto and Jimenez-Rueda, 2007, Bonotto et al., 2017).

The objective of this paper is to report the results of chemical analysis of the major constituents and both $U$-isotopes ${ }^{238} \mathrm{U}$ and ${ }^{234} \mathrm{U}$ in samples of three soil profiles developed over sandstones from the Paraná basin (Minas Gerais State, Brazil), and to evaluate the progression of the weathering front in a catena with contrasted soil-water regime.

\section{Study area}

The catena is composed of Ferralsol-Gleysol (FAO, 2006) transition developed on sandstone of Marilia formation (Neocretaceous). It is located at western of Minas Gerais State (Brazil), at $18^{\circ} 56^{\prime} \mathrm{S}$ and $48^{\circ} 9^{\prime} \mathrm{W}$ (Fig. 1), on a flat plateau at $1050 \mathrm{~m}$ elevation. The plateau is a segment of the Brazilian Central Plateau covered by cerrado (Brazilian savannah). The climate is characterized by a pronounced dry season (April - October) and rainfall during the summer months (November March). The average annual rainfall and temperature are $1516 \mathrm{~mm}$ and $23{ }^{\circ} \mathrm{C}$, respectively. The geology is characterized by sandstone with iron-rich clay layers of the Serra da Galga Member of the Marília Formation (Upper Cretaceous) (Fernandes, 2004).

The soil in the catena is composed of reddish-yellow to yellow Ferralsol in the higher and well-drained segment of the plateau and Gleysol in the bottom with poorly-drained topographic depressions

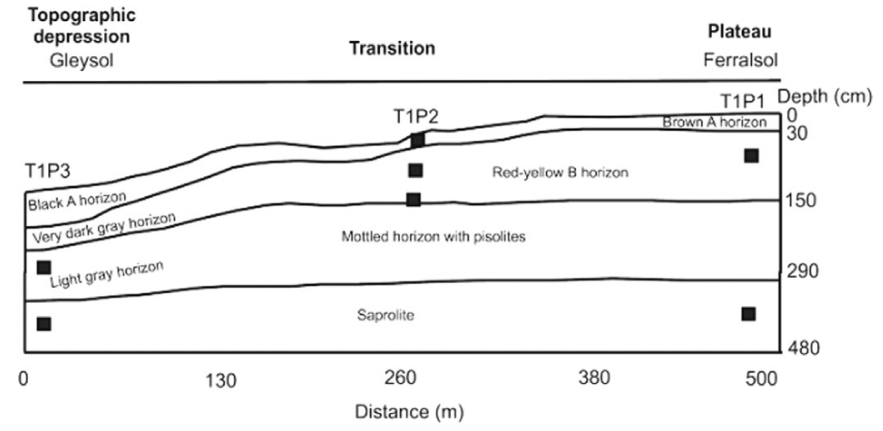

Fig. 2. Sketch of the catena with the tree studied profiles (T1P1, T1P2 and T1P3). The black squares represent the location of soil samples.

(Fig. 2). The soils have a low $\mathrm{pH}$ and are composed of kaolinite, hematite, goethite, gibbsite, and residual quartz. The Ferralsol (profile T1P1) is derived from the sandstone and presents accumulation of iron (pisolites) in the mottled horizon, probably as a result of old ferricrete dissolution. The Gleysol (profile T1P3) is located in a topographic depression and is considered the profile developed by the transformation of Ferralsol under new soil-environmental conditions. The profile T1P2 is located in the intermediate segment of the slope (between T1P1 and T1P3), representing the transition zone. The soil descriptions are in Table 1.

\section{Sampling and analytical methods}

In profile T1P1, the soil was sampled at $30-83$ and $360-390 \mathrm{~cm}$ depth, corresponding to sub-superficial horizon and saprolite, respectively. In profile T1P2, the samples were collected at 0-5 cm, 50-63 cm and $100-110 \mathrm{~cm}$ depth, corresponding to superficial, sub-superficial and mottled with pisolites horizons, respectively. In profile T1P3, the soils were sampled at $92-110$ and $250-280 \mathrm{~cm}$ depth, representing the iron-depleted horizon with pisolites and the saprolite (Fig. 2).

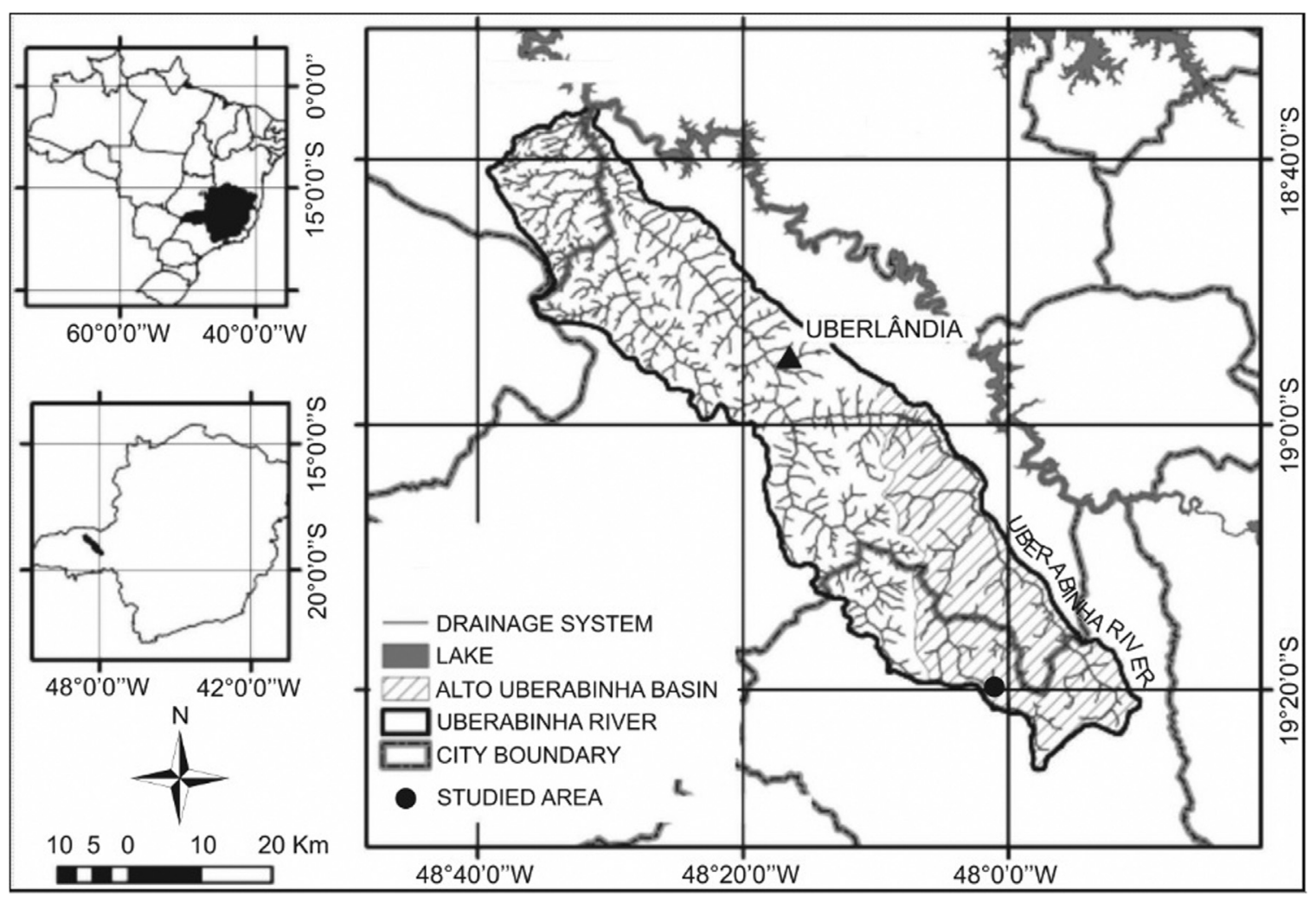

Fig. 1. Localization of the area of the study. Plateau located in the Triângulo Mineiro (Western of Minas Gerais State, Brazil). 
Table 1

General soil descriptions from T1P1, T1P2 and T1P3 profiles. Based on IUSS Working Group WRB (2014).

\begin{tabular}{|c|c|c|}
\hline Profile/Horizon & Depth (cm) & Description \\
\hline \multicolumn{3}{|l|}{ T1P1 (FR) $)^{\mathrm{a}}$} \\
\hline A & $0-30$ & Yellowish brown (10YR 5/4) with zones more yellow (10YR 5/6); clay; massive; common fine to medium vesicular pores. \\
\hline B1 & $30-122$ & $\begin{array}{l}\text { Yellowish brown (10YR 5/4); clay; fine granular structure; } 5 \% \text { of ferruginous nodules; few vesicular pores commonly in-filled by more yellow } \\
\text { clay; diffuse boundary. }\end{array}$ \\
\hline B2 & $122-150$ & Strong brown (7.5YR 5/6); clay; moderate fine granular structure; $5 \%$ of ferruginous nodules; diffuse boundary. \\
\hline Bg1 & $150-250$ & Reddish yellow (7.5YR 6/6) with common mottles yellowish red (5YR 5/8); clay, massive; gradual boundary. \\
\hline Bg2 & 250-290 & Reddish yellow (7.5YR 6/6) with fine mottles yellowish red (5YR 5/8); clay, massive; gradual boundary. \\
\hline $\mathrm{BgC}$ & $290-480$ & $\begin{array}{l}\text { Reddish yellow (7.5YR 6/6) with fine spots red (2.5YR 5/8) and yellowish red (5YR 5/8); clay, massive to layered structure (highly weathered } \\
\text { argilous-sandstone saprolite). }\end{array}$ \\
\hline \multicolumn{3}{|r|}{ 然 } \\
\hline A & $0-28$ & $\begin{array}{l}\text { Dark yellowish brown (10YR 4/6 to 10YR 3/4); clay; fine granular; common biological voids in- filled with clay dark greyish brown (10YR } 4 / 2 \text { ), } \\
\text { termite burrows and insect nests; very fine roots of grass and few fine of shrubs; diffuse boundary. }\end{array}$ \\
\hline $\mathrm{AB}$ & 28-39 & $\begin{array}{l}\text { Yellowish brown (10YR 5/6); clay; moderate granular to weak blocky subangular; fine roots of grass and few fine of shrubs; biological voids in- } \\
\text { filled with clay dark greyish brown (10YR 4/2), termite burrows; diffuse boundary. }\end{array}$ \\
\hline B1 & $39-49$ & $\begin{array}{l}\text { Yellowish brown (10YR 5/6); clay; massive to weak blocky subangular; fine roots of grass and few fine of shrubs; biological voids in- filled with } \\
\text { clay dark greyish brown (10YR 4/2) with weak granular structure, termite burrows; diffuse boundary. }\end{array}$ \\
\hline B2 & 49-65 & $\begin{array}{l}\text { Yellowish brown (10YR } 5 / 6) \text { to brownish yellow (10YR } 5 / 6) \text {; clay; } 5 \% \text { of ferruginous red and yellow nodules; massive; biological voids in- filled } \\
\text { with clay dark greyish brown (10YR 4/2); clear boundary. }\end{array}$ \\
\hline Bg1 & 65-112 & $\begin{array}{l}\text { Mottled brownish yellow (10YR 6/6) and red (2.5YR } 5 / 6) \text { with vertical spots light yellowish brown (10YR } 6 / 4) \text {; clay; massive, coherent; } 15 \% \text { of } \\
\text { ferruginous dark red (10R 4/8) nodules; biological voids in-filled with clay grayish brown }(10 \mathrm{YR} 5 / 2) \text {. }\end{array}$ \\
\hline \multicolumn{3}{|r|}{ (1) } \\
\hline A & $0-12$ & $\begin{array}{l}\text { Very dark grayish brown (10YR 3/2) to blak (7.5YR 2.5/1) to with few medium faint spots dark grayish brown (10YR 4/2); clay; many very fine } \\
\text { roots of grass; weak granular and blocky structure; medium cracks, very deep, closely spaced; gradual boundary. }\end{array}$ \\
\hline A2 & $12-29$ & $\begin{array}{l}\text { Dark grayish brown (10YR 4/2); clay; many very fine roots of grass; weak granular and blocky structure; medium cracks, very deep, closely } \\
\text { spaced; very fine roots; gradual boundary. }\end{array}$ \\
\hline Bg1 & 29-81 & $\begin{array}{l}\text { Gray (7.5YR 5/1) with abundant fine mottles white (10YR 8/1); clay; massive; medium cracks, very deep, closely spaced with iron impregnation } \\
\text { brownish yellow (10YR 6/6); very fine roots; clear boundary. }\end{array}$ \\
\hline Bg2 & $81-150$ & Light gray (10YR 7/1) with many fine mottles red (10R 4/6 and 10R 4/8); clay; massive; gradual boundary. \\
\hline $\mathrm{BgC}$ & $150-460$ & $\begin{array}{l}\text { Mottled brownish yellow (10YR 6/8) and very pale brown (10YR 8/2); clay; massive to layered structure (highly weathered argilous-sandstone } \\
\text { saprolite). }\end{array}$ \\
\hline
\end{tabular}

\footnotetext{
${ }^{\mathrm{a}} \mathrm{FR}=$ Ferralsol.

${ }^{\mathrm{b}} \mathrm{GL}=$ Gleysol.
}

The profiles of Ferralsol (T1P1 and T1P2) and Gleysol (T1P3) have in common the presence of mottled horizons in the lower position of the profiles indicating alternate reducing and oxidizing conditions (FAO, 2006). In the T1P1 and T1P2, the superficial and sub-superficial horizons are well drained and are underlying by a mottled horizon (yellowish and reddish spots) with pisolites. These were underlain by a high weathered saprolite with layered structure from argilous-sandstone. The profile T1P3 has higher amounts of organic matter in the superficial horizons which overlies the iron-depleted (light gray) horizon. The mottled horizon with pisolites and the saprolite are similar to those described for T1P1 and T1P2, however, they have lower iron concentration due to the long duration of water stagnation.

The samples were placed in plastic bags, transported to the laboratory, sieved to $2 \mathrm{~mm}$ for removing roots, leaves and other coarse materials. Then, they were crushed, quartered, sieved for separation of the $<200$ mesh $(<74 \mu \mathrm{m})$ size fraction. Major chemical elements were determined by X-ray fluorescence (XRF Philips PW 2400 spectrometer). The detection limits were on the order of $0.1 \mathrm{~g} \mathrm{~kg}^{-1}$ for $\mathrm{SiO}_{2}, \mathrm{Al}_{2} \mathrm{O}_{3}$, and $\mathrm{Fe}_{2} \mathrm{O}_{3}$ and on the order of $0.01 \mathrm{~g} \mathrm{~kg}^{-1}$ for $\mathrm{MgO}, \mathrm{CaO}, \mathrm{Na}_{2} \mathrm{O}, \mathrm{K}_{2} \mathrm{O}$, and $\mathrm{TiO}_{2}$. The average concentrations of the $\mathrm{SiO}_{2}, \mathrm{Al}_{2} \mathrm{O}_{3}, \mathrm{Fe}_{2} \mathrm{O}_{3}$ obtained for the bedrock are $40.29 \%, 21.68 \%$, and $26.13 \%$, respectively. The $\mathrm{pH}$ was measured potentiometrically in a $0.01 \mathrm{M} \mathrm{CaCl}_{2}$ solution (1:1 soil to solution ratio). Total Organic Carbon (TOC) was determined by the Walkley-Black method, and the total $\mathrm{P}$ was extracted with the extractant Mehlich $(2.5 \mathrm{~g}$ of soil: $25 \mathrm{~mL}$ of $0.05 \mathrm{M} \mathrm{HCl}$ and $0.0125 \mathrm{M}$ $\mathrm{H}_{2} \mathrm{SO}_{4}$ ) and determined by colorimetry. The results of the analyses are shown in Table 2.

The U-isotopes analysis were made according to Bonotto et al. (2017). The aliquots between 1 and $3 \mathrm{~g}$ were digested with aqua regia $\left(1: 3 \mathrm{HNO}_{3}-\mathrm{HCl}\right)$. Then, a $3.39 \mathrm{dpm}$ of ${ }^{232} \mathrm{U}$ spike was added into solution. After dryness and dissolution in $8 \mathrm{M} \mathrm{HCl}, \mathrm{Fe}^{3+}$ was extracted into an equal volume of isopropyl ether. The acid U-bearing solution was purified by anion exchange, first on $\mathrm{a} \mathrm{Cl}^{-}$and then on a $\mathrm{NO}_{3}{ }^{-}$column of
100-200 mesh Dowex ion exchange resin. $U$ was finally eluted from the $\mathrm{NO}_{3}{ }^{-}$column with $0.1 \mathrm{M} \mathrm{HCl}$ and after evaporation to dryness was dissolved in $10 \mathrm{~mL}$ of $2 \mathrm{M}\left(\mathrm{NH}_{4}\right)_{2} \mathrm{SO}_{4}$ electrolyte and transferred to an electrodeposition cell. The $\mathrm{pH}$ was adjusted to 2.4 and electrodeposition of $\mathrm{U}$ on a stainless steel planchet was complete after $3 \mathrm{~h}$ at a current density of $1 \mathrm{Acm}^{-2}$. The $\mathrm{U}$ content was measured by alpha spectrometry. The $\alpha$-activities were determined with four $0.1 \mathrm{~mm}$ depletion depth, 200/450 $\mathrm{mm}^{2}$ area silicon surface barrier detectors. The spectra for natural $\mathrm{U}$ and ${ }^{232} \mathrm{U}$ tracer extracted were recorded on an EG\&G ORTEC 919 Spectrum Master Multichannel Buffer. The Decision Level Lc (Currie, 1968) for acceptance of a positive measurement in the ${ }^{238} \mathrm{U}$ and ${ }^{232} \mathrm{U}$ energy regions was 0.00082 and $0.00225 \mathrm{cpm}$, respectively. The $\mathrm{U}$ concentration was calculated by isotope dilution from the counting rates of ${ }^{238} \mathrm{U}$ and ${ }^{232} \mathrm{U}$ peaks, whereas the ${ }^{234} \mathrm{U} /{ }^{238} \mathrm{U}$ activity ratio (AR) from the counting rates of ${ }^{238} \mathrm{U}$ and ${ }^{234} \mathrm{U}$ peaks. Table 3 reports the results of the U-isotopes analyses.

\section{Results and discussion}

\subsection{Chemical composition of the soil horizons}

The total oxides determined in the profiles (Table 2) show very low concentrations of the alkaline and alkaline-earth elements $(<0.4 \%)$. The range of $\mathrm{Fe}_{2} \mathrm{O}_{3}$ in T1P1 is small, from $8 \%$ to $9 \%$ in the profile. The range in T1P2 is greater, varying from $7 \%$ to $11 \%$. The highest contents of iron oxides is related to the presence of pisolites in the horizons $\mathrm{Bg} 1$ and $\mathrm{Bg} 2$. The lower concentration of $\mathrm{Fe}_{2} \mathrm{O}_{3}$ in T1P3 is due to the water table influence in the topographic depression, resulting in the presence of mottles and iron-depleted horizon. Generally, the amount of the $\mathrm{Fe}_{2} \mathrm{O}_{3}$ is higher in the mottled horizons and in the well-drained profile.

The lowest concentrations of iron are determined in T1P3 in which the Fe oxide-depleted matrix appears (light gray color) suggesting long duration (many weeks to months) of water saturation and iron- 
Table 2

Total concentrations of oxides, chemical mobility of major elements, $\mathrm{pH}$, Total Organic Carbon (TOC) and Total P with soil depth in profiles T1P1, T1P2, and T1P3.

\begin{tabular}{|c|c|c|c|c|c|c|c|c|c|c|c|c|}
\hline \multirow[t]{2}{*}{ Horizon/Profile } & \multirow[t]{2}{*}{ Depth $(\mathrm{cm})$} & \multicolumn{5}{|c|}{ Total oxides (\%) } & \multicolumn{3}{|c|}{ Chemical mobility $(\mathrm{X} / \mathrm{Ti})$} & \multirow[t]{2}{*}{$\mathrm{pH}\left(\mathrm{CaCl}_{2}\right)$} & \multirow{2}{*}{$\begin{array}{l}\text { TOC } \\
\text { mmol/L }\end{array}$} & \multirow[t]{2}{*}{ Total P } \\
\hline & & $\mathrm{SiO}_{2}$ & $\mathrm{Al}_{2} \mathrm{O}_{3}$ & $\mathrm{Fe}_{2} \mathrm{O}_{3}$ & $\mathrm{TiO}_{2}$ & Base Cations & $\mathrm{Si}$ & $\mathrm{Fe}$ & $\mathrm{Al}$ & & & \\
\hline \multicolumn{13}{|l|}{ T1P1 (FR) } \\
\hline A & $0-30$ & 27.4 & 39.1 & 8.5 & 2.8 & 0.15 & 0.04 & 1.1 & 1.7 & 4.3 & 15 & 4 \\
\hline B1 & $30-83$ & 23.6 & 43.3 & 8.5 & 3.1 & 0.09 & 0.03 & 1.0 & 1.7 & 4.7 & 10 & 3 \\
\hline B2 & $122-125$ & 23.7 & 44.6 & 8.1 & 3.2 & 0.10 & n.d. & n.d. & n.d. & n.d. & n.d. & n.d. \\
\hline $\mathrm{Bg} 1$ & $150-170$ & 24.1 & 43.9 & 8.1 & 3.3 & 0.24 & 0.03 & 0.9 & 1.7 & n.d. & n.d. & n.d. \\
\hline $\mathrm{Bg} 1$ & $200-220$ & 20.4 & 39.2 & 8.0 & 2.9 & 0.10 & 0.03 & 1.0 & 1.7 & 5.7 & 2 & 2 \\
\hline $\mathrm{Bg} 2$ & $250-260$ & 23.9 & 45.1 & 8.1 & 3.3 & 0.09 & 0.03 & 0.9 & 1.7 & 6.0 & $<1$ & 2 \\
\hline $\mathrm{Bg} 2$ & $260-280$ & 24.2 & 45.5 & 8.8 & 3.3 & 0.10 & 0.03 & 1.0 & 1.7 & n.d. & n.d. & n.d. \\
\hline $\mathrm{BgC}$ & $290-310$ & 23.0 & 44.8 & 9.1 & 3.2 & 0.09 & 0.03 & 1.0 & 1.8 & 6.3 & $<1$ & 2 \\
\hline $\mathrm{BgC}$ & $330-360$ & 24.9 & 44.8 & 8.5 & 3.1 & 0.13 & 0.03 & 1.0 & 1.8 & 6.3 & $<1$ & 2 \\
\hline \multicolumn{13}{|l|}{ T1P2 (FR) } \\
\hline A & $0-5$ & 19.8 & 43.9 & 7.1 & 3.7 & 0.07 & 0.02 & 0.7 & 1.5 & 4.1 & 30 & 8 \\
\hline A & 5-13 & 19.9 & 44.2 & 7.2 & 3.7 & 0.11 & 0.02 & 0.7 & 1.5 & 4.1 & 21 & 7 \\
\hline $\mathrm{AB}$ & $13-30$ & 19.7 & 45.4 & 6.7 & 3.8 & 0.08 & 0.02 & 0.6 & 1.5 & 4.3 & 17 & 4 \\
\hline B1 & $30-49$ & 21.2 & 44.6 & 8.1 & 3.6 & 0.18 & 0.02 & 0.8 & 1.5 & 4.1 & 30 & 8 \\
\hline B2 & 49-65 & 26.4 & 42.3 & 7.6 & 3.5 & 0.08 & 0.02 & 0.8 & 1.5 & 5.2 & 6 & 2 \\
\hline $\mathrm{Bg} 1$ & $76-110$ & 26.4 & 39.7 & 11.1 & 3.2 & 0.10 & 0.04 & 0.8 & 1.5 & n.d. & n.d. & n.d. \\
\hline $\mathrm{Bg} 2$ & $110-170$ & 23.0 & 44.1 & 9.2 & 3.6 & 0.08 & 0.03 & 1.3 & 1.5 & 5.7 & $<1$ & 2 \\
\hline Bg2 & $170-230$ & 24.1 & 43.6 & 9.1 & 3.5 & 0.41 & 0.02 & 0.9 & 1.5 & 6.0 & $<1$ & 3 \\
\hline $\mathrm{BgC1}$ & $230-370$ & 32.1 & 41.9 & 6.9 & 2.7 & 0.14 & 0.05 & 0.9 & 1.8 & 6.0 & $<1$ & 3 \\
\hline \multicolumn{13}{|l|}{ T1P3 (GL) } \\
\hline A & $0-2$ & 20.7 & 40.0 & 3.8 & 2.9 & 0.23 & 0.03 & 0.4 & 1.7 & 4.3 & 50 & 10 \\
\hline A & $2-12$ & 20.9 & 44.2 & 3.5 & 3.3 & 0.14 & 0.03 & 0.4 & 1.7 & 4.1 & 50 & 7 \\
\hline A2 & $12-20$ & 21.7 & 47.4 & 2.6 & 3.5 & 0.16 & 0.03 & 0.2 & 1.7 & 4.8 & 25 & 2 \\
\hline $\mathrm{Bg} 1$ & $33-69$ & 22.8 & 48.7 & 3.2 & 3.6 & 0.09 & 0.03 & 0.3 & 1.6 & 5.1 & 9 & 2 \\
\hline Bg1 & $73-81$ & 23.5 & 48.0 & 2.3 & 3.5 & 0.08 & 0.02 & 0.3 & 1.7 & 5.0 & 14 & 1 \\
\hline $\mathrm{Bg} 2$ & 84-88 & 29.3 & 46.3 & 1.5 & 3.1 & 0.06 & 0.02 & 0.3 & 1.7 & 5.4 & 6 & 2 \\
\hline $\mathrm{Bg} 3$ & $92-110$ & 39.7 & 35.8 & 2.4 & 2.2 & 0.28 & 0.08 & 0.3 & 2.5 & 5.9 & $<1$ & 2 \\
\hline Bg3 & $110-150$ & 24.3 & 45.0 & 7.6 & 3.3 & 0.10 & 0.03 & 0.8 & 1.7 & 6.1 & 2 & 1 \\
\hline $\mathrm{BgC}$ & $150-170$ & 23.8 & 44.4 & 9.2 & 3.2 & 0.12 & 0.03 & 1.0 & 1.7 & 5.8 & $<1$ & 1 \\
\hline $\mathrm{BgC}$ & $200-210$ & 25.9 & 45.9 & 6.2 & 3.3 & 0.08 & 0.03 & 0.7 & 1.8 & n.d. & n.d. & n.d. \\
\hline $\mathrm{BgC}$ & $210-260$ & 28.1 & 44.6 & 6.0 & 2.9 & 0.07 & 0.04 & 0.7 & 1.9 & 5.6 & $<1$ & 2 \\
\hline $\mathrm{BgC}$ & $290-300$ & 33.7 & 42.7 & 4.5 & 2.8 & 0.08 & 0.06 & 0.6 & 1.9 & 6.1 & $<1$ & 3 \\
\hline $\mathrm{BgC}$ & $300-360$ & 40.4 & 39.8 & 3.2 & 2.5 & n.d. & 0.07 & 0.4 & 2.0 & n.d. & n.d. & n.d. \\
\hline
\end{tabular}

n.d. = not measured.

Table 3

U-isotopes analysis and ages from ARs disequilibria data.

\begin{tabular}{lllll}
\hline Profile (depth) & Horizon & $\begin{array}{l}\mathrm{U}^{\mathrm{a}} \\
\mu \mathrm{g} / \mathrm{g}\end{array}$ & $\begin{array}{l}{ }^{234} \mathrm{U} /{ }^{238} \mathrm{U} \\
\mathrm{AR}^{\mathrm{a}}\end{array}$ & $\begin{array}{l}\text { Age } \\
(\mathrm{Ma})\end{array}$ \\
\hline T1P1 $(30-80 \mathrm{~cm})$ & Subsuperficial & 0.82 & 0.98 & - \\
T1P1 $(360-390 \mathrm{~cm})$ & Saprolite & 0.18 & 1.59 & 1.05 \\
T1P2 $(5 \mathrm{~cm})$ & Superficial & 25.62 & 0.15 & 1.18 \\
T1P2 $(63 \mathrm{~cm})$ & Subsuperficial & 7.77 & 0.81 & 0.64 \\
T1P2 $(110 \mathrm{~cm})$ & Mottled & 0.65 & 1.56 & 1.03 \\
T1P3 $(92-110 \mathrm{~cm})$ & Iron depleted & 0.27 & 1.19 & 0.64 \\
T1P3 $(280 \mathrm{~cm})$ & Saprolite & 0.19 & 1.00 & - \\
\hline
\end{tabular}

a Analytical uncertainty $\pm 10-15 \%$ at $1 \sigma$ standard deviation.

reduction (Vepraskas, 2004). Fe is a redox-sensitive element and could be easily depleted in hydromorphic soil. In the profiles T1P1 and T1P2, the iron oxides are concentrated in the mottled horizon due to the presence of pisolites. In general, $\mathrm{SiO}_{2}$ and $\mathrm{Al}_{2} \mathrm{O}_{3}$ have an antagonistic relationship. The $\mathrm{Al}_{2} \mathrm{O}_{3}$ increases in the upper horizons and $\mathrm{SiO}_{2}$ diminishes $(r=-0.95$ in T1P2, and $r=-0.63$ in T1P3, where $\mathrm{P}<0.05)$. Generally the horizons with more organic matter also has an increase in $\mathrm{P}$, despite low levels of $\mathrm{P}$ determined in the deeper horizons (Bg2 and $\mathrm{BgC}$ in $\mathrm{T} 1 \mathrm{P} 1, \mathrm{Bg} 2$ and $\mathrm{BgC} 1$ in $\mathrm{T} 1 \mathrm{P} 2$ and $\mathrm{Bg} 3$ and $\mathrm{BgC}$ in T1P3) are unrelated to the TOC. The increase of soil organic matter is significant and negatively correlated to the $\mathrm{pH}$ in the profiles T1P2 and $\mathrm{T} 1 \mathrm{P} 3(\mathrm{r}=0.79$ in T1P1, $\mathrm{r}=-0.91$ in T1P2, and $\mathrm{r}=-0.94$ in T1P3). The chemical mobility within the profiles is variable from upslope to downslope of the catena (Table 2).

When compared to the sandstone, the profile T1P1 is enriched in iron, and the profiles $\mathrm{T} 1 \mathrm{P} 2$ and $\mathrm{T} 1 \mathrm{P} 3$ present a progressive impoverishment of iron due to the progressive increase of hydromorphic conditions. The chemical enrichment of $\mathrm{Al}_{2} \mathrm{O}_{3}$ in all profiles is associated to the presence of gibbsite. The reducing environment leads to the deferruginization and to the enrichment of organic matter, reducing the $\mathrm{pH}$ of the soil solution. The acidity in the depression $\mathrm{pH} \sim$ 4.3-4.6) may allow the dissolution of kaolinite and remains at the $\mathrm{pH}$ limit of gibbsite dissolution ( $\mathrm{pH}<4)$ (Tardy, 1993).

The relative contents among these oxides is considered as the typical geochemical evolution of strongly weathered tropical soils where cations and silica are lost from the profiles, and iron and aluminum remain as residual products (Melfi, 1997). In this case, the iron depletion and concentration in profiles is related to the fluctuation and permanence of localized perched groundwater tables.

The mineralogical composition of soils is represented by kaolinite, hematite, goethite and gibbsite. The spectrum of kaolinite $(0.7 \mathrm{~nm})$ is pronounced in greater soil depth while the spectrum of gibbsite $(0.4 \mathrm{~nm})$ is pronounced in superficial horizons.

\subsection{Uranium concentration and ${ }^{234} U /{ }^{238} U$ activity ratio (AR) in the horizons of the soil profiles}

The $\mathrm{SiO}_{2}$ content of the samples was higher than the $\mathrm{Al}_{2} \mathrm{O}_{3}$ concentration only at T1P3 profile $(92-110 \mathrm{~cm}$ depth) (Table 2). Thus, alumina was the major oxide of the saprolites and practically all horizons of both soil profiles (Table 2). Iron oxides have been shown to play an important role in the mechanisms that control the U-Th distribution in the tropical saprolite, soils and other contexts as identified by Dodge et al. (2002), Chabaux et al. (2003), Stubbs et al. (2006), Romero-González et al. (2007), Marshall et al. (2014) and Bonotto et al. 
(2017), among others. However, such trend was not found from the available data for the study area as the Pearson correlation coefficient between the $\mathrm{U}$ and $\mathrm{Fe}_{2} \mathrm{O}_{3}$ concentrations is only 0.10. Uranium also does not accumulate in the soil horizons associated with $\mathrm{SiO}_{2}, \mathrm{Al}_{2} \mathrm{O}_{3}$, $\mathrm{TiO}_{2}$ and bases as no significant correlation was found among their concentrations. There is as well no evidence of its incorporation intact in the coarser grained fraction of the soil horizons or in resistates/minor refractory minerals (such as zircon) that are highly resistant to weathering like reported by Bonotto and Jimenez-Rueda (2007).

Szalay (1964) pointed out the organic matter (OM) importance on the uranium adsorption, considering that the accumulation of this element occurs after the plants decomposition, whose lignin partially transforms in insoluble humic acids during the humification process. The experiments of Szalay (1964) indicated that the adsorption mechanism in which the humic acids concentrate the uranium dissolved in natural waters is a cation exchange process. Pauli (1975) performed laboratory experiments with a material derived from weathered lignin in order to study the mechanisms involved as it exhibited adequate properties for adsorption of heavy metals. Humic complexes of $\mathrm{UO}_{2}{ }^{2+}$, $\mathrm{Pb}, \mathrm{Cu}, \mathrm{Zn}, \mathrm{Ni}$ and $\mathrm{Cd}$ were obtained on adding different amounts of powdered materials to the humus suspension of variable concentration. The results indicated that the uranyl ion $\left(\mathrm{UO}_{2}{ }^{2+}\right)$ combines with the humic compound utilized in a more accentuated proportion and much faster than the others metallic ions (Pauli, 1975). Such findings may justify the significant correlation between the TOC and U contents in the whole database (Fig. 3).

The inverse relationship between $\mathrm{pH}$ and TOC also implies on an inverse correlation between $\mathrm{pH}$ and $\mathrm{U}$ concentration (Fig. 3). The ${ }^{234} \mathrm{U} /{ }^{238} \mathrm{U}$ activity ratio (AR) exhibited an inverse relationship with the U content (Fig. 3) and, consequently, direct and opposite trends were verified for the ARs values when correlated with the $\mathrm{pH}$ and TOC contents, respectively (Fig. 3).

\subsection{Possible timescales of the soil horizons formation from U-isotopes disequilibria}

The more superficial T1P1 soil horizon $(30-80 \mathrm{~cm})$ and T1P3 saprolite exhibit ARs corresponding to unit, within experimental errors, indicating radioactive equilibrium between ${ }^{234} U$ and ${ }^{238} U$ in these matrices at least over the last one million years (Latham and Schwarcz, 1987). Thus, there is no occurrence at these sites of extra ${ }^{234} \mathrm{U}$-loss either due to $\alpha$-recoil effects (Kigoshi, 1971) or by preferential leaching/ etching of recoil-damaged sites (Fleischer, 1975). However, preferential removal or accumulation of ${ }^{234} \mathrm{U}$ has occurred at other (mottled) soil horizons and saprolite, generating ARs $<1$ or ARs $>1$, within experimental errors, a typical result related to the effect of rock/soil-water interactions (Osmond and Cowart, 1976). The water table fluctuations in the soil profiles along different timescales have favored the production of ARs $>1$ for uranium dissolved in the liquid phase, and, consequently, ARs $<1$ in the solid phase. Additionally, evapotranspiration processes affecting the uranium dissolved in the liquid phase enriched in ${ }^{234} \mathrm{U}$ may have also caused the generation of ARs $>1$ in the solid phase.

Thus, equivalent $\mathrm{U}$-isotopes dissolution by infiltrating more oxidizing rainwater yielded $\mathrm{ARs}=1$, within experimental errors. But, the oxidation of $\mathrm{U}$ to the more soluble, hexavalent state (Langmuir, 1978) has been favored by the acidity increase due to the humic and fulvic acids release from the organic matter decomposition. Consequently, the ${ }^{238} \mathrm{U}$-enrichment in the more acid conditions implied on decreased ARs, generating values that are greatly out of equilibrium, within
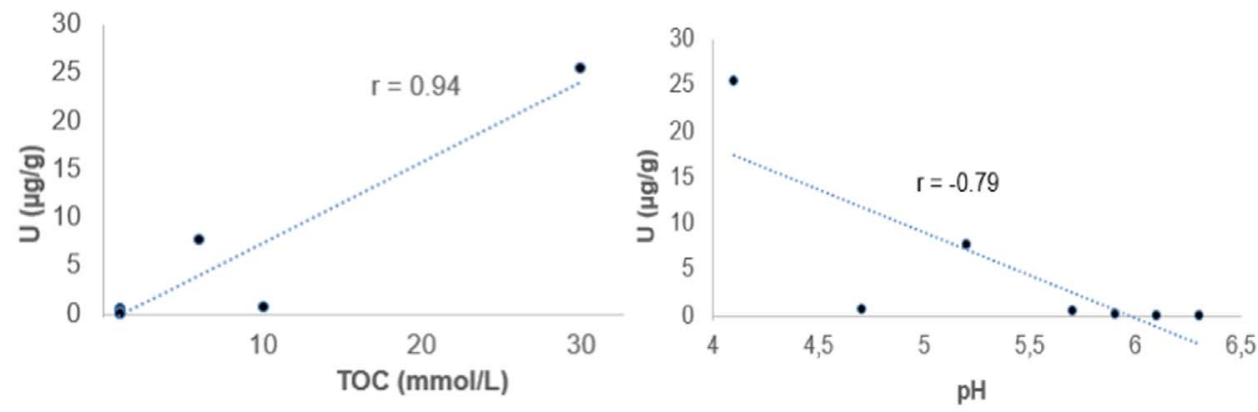

Fig. 3. The relationships among the $\mathrm{pH}, \mathrm{AR}, \mathrm{U}$ concentration and TOC concentration.
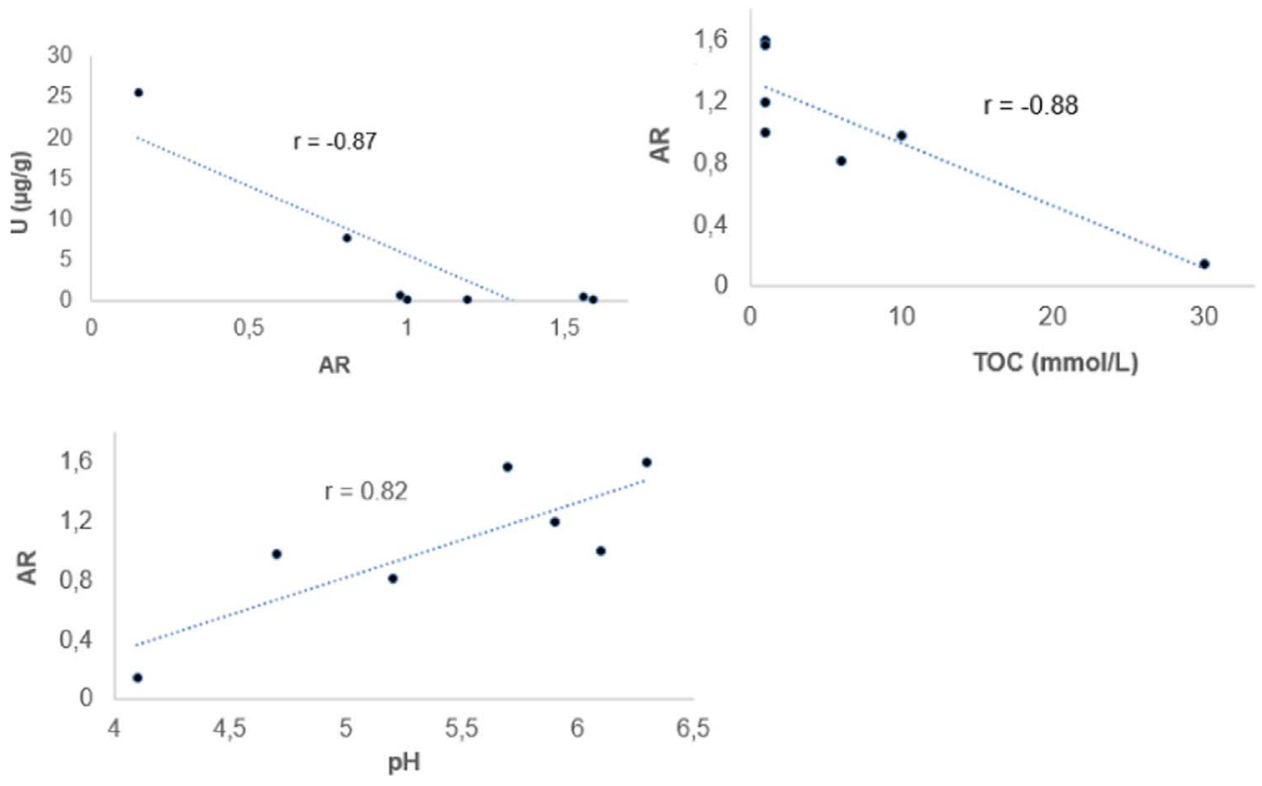
experimental errors. They may supply timing information concerning to the water-weathered profile interactions in the area. These disequilibria allow to calculate an "apparent time" representing the state of disequilibrium acted against by the decay back to equilibrium of the shorter-lived daughter. This time $(t)$ may be expressed for relative daughter deficiency by $t=-1 / \lambda \ln (1-D / P)$ where $\lambda$ is the decay constant of the daughter $\left({ }^{234} \mathrm{U}\right.$ in the present case $)$ and $D / P$ is the activity of a daughter $(D)$ to its parent $(P)\left({ }^{234} \mathrm{U} /{ }^{238} \mathrm{U}\right.$ in the present case) (Latham and Schwarcz, 1987). The time needed to restore the system to equilibrium from deficiency may be calculated by the use of the quantity $5 H F-t$ ( $H F$ is the half-life of ${ }^{234} \mathrm{U}$ ) (Latham and Schwarcz, 1987). Thus, taking into account the ARs $<1$ values of 0.15 (T1P2, $5 \mathrm{~cm}$ ) and $0.81(\mathrm{~T} 1 \mathrm{P} 2,63 \mathrm{~cm})$ it is possible to obtain $1.18 \mathrm{Ma}$ and $0.64 \mathrm{Ma}$ (Table 3), respectively, as the time to restore the equilibrium, which may represent the elapsed time for developing these horizons.

In the case of the ARs $>1$ ratios in the solid phase, the ${ }^{234} \mathrm{U}$-excess values allow estimate the time $(t)$ to decay back to equilibrium according to the equation $t=-1 / \lambda \ln (D / P-1)$ where $D / P$ is the ${ }^{234} \mathrm{U} /{ }^{238}$ Uactivity ratio above unity (Latham and Schwarcz, 1987). The time needed to decay back to equilibrium from the ${ }^{234} \mathrm{U}$-excess may be also calculated by the formula $5 H F-t$ ( $H F$ is the half-life of ${ }^{234} \mathrm{U}$ ) (Latham and Schwarcz, 1987). Therefore, taking into account the ARs $>1$ values of $1.59(\mathrm{~T} 1 \mathrm{P} 1,360 \mathrm{~cm}), 1.56(\mathrm{~T} 1 \mathrm{P} 2,110 \mathrm{~cm}-$ mottled) and $1.19(\mathrm{~T} 1 \mathrm{P} 3,92-110 \mathrm{~cm})$ it is possible to obtain $1.05 \mathrm{Ma}, 1.03 \mathrm{Ma}$ and $0.64 \mathrm{Ma}$ (Table 3), respectively, as the time to the ${ }^{234} \mathrm{U}$-excess decay back to equilibrium.

The results suggest that the set of soil horizons in the slope is in disequilibrium. The oldest soil profile (T1P1) and the deep mottled horizon in T1P2 have a small gap of ages 1.03-1.18 Ma). The more recent ages ( $0.64 \mathrm{Ma}$ ) were obtained in T1P2 at $63 \mathrm{~cm}$ (drained horizon with yellow color) and in T1P3 at $92-110 \mathrm{~cm}$ (iron-depleted horizon). The profile T1P2 is strongly influenced by termites and at $63 \mathrm{~cm}$ was usually recognized biogenic aggregates surrounded by a network of pores produced by the organisms. These soil features are interrupted at the boundary of the mottled horizon. This site is known as earthmound developed in close association with the cerrado (savanna woodland) (Ponce and Cunha, 1993). The earthmounds are formed through a long process involving the colonization by termites activities producing structures after grind soil particles by mandibles and salive, reorganizing the physical and chemical constitution of soil horizon (Bottinelli et al., 2015). In the T1P3 $(92-110 \mathrm{~cm})$, the soil environment is deeply affected by the front of transformation. The hydromorphy cause a complete dissolution and leaching of iron out of the soil profile, causing the destabilization and eluviation of clay particles from the depleted zone, modifying deeply the soil structure (Lucas and Chauvel, 1992). Also, the presence of organic acid as a product of decomposition of soil organic matter in hydromorphic environment influences the geochemical weathering. This is a current and recent process, which renew the soil cover and evolves to new balancing according the pedogenesis advance.

\section{Conclusion}

The soil cover is a dynamic system and the uranium isotope method can help to elucidate the biogeochemical processes involved in the time scale. The major chemical composition and radioactivity due to uranium isotopes ${ }^{238} \mathrm{U}$ and ${ }^{234} \mathrm{U}$ in horizons of three soil profiles were determined with the aim of evaluating the weathering processes and estimating the formation age through the U-isotopes disequilibrium technique. Uranium does not accumulate in the soil horizons associated with $\mathrm{Fe}_{2} \mathrm{O}_{3}, \mathrm{SiO}_{2}, \mathrm{Al}_{2} \mathrm{O}_{3}, \mathrm{TiO}_{2}$ as expected in lateritic soil. In the contrasted soil-water regime, the positive and significant correlation was obtained between uranium and soil organic matter, which increase associated with the soil hydromorphy. The ${ }^{238} \mathrm{U}$ and ${ }^{234} \mathrm{U}$ disequilibria data allowed an estimate of "apparent ages" representing the state of disequilibrium acted against by the trend to decay back to equilibrium of the shorter-lived daughter ${ }^{234} \mathrm{U}$. The hydromorphy is a new process (the age 0.64 Ma was obtained in the iron depleted horizon) that advance in the older lateritic profile (Ferralsol with an age of 1.18-1.05 Ma). Exception is determined in the horizon of soil deeply affected by organic activity, suggesting that the soil bioturbation has an important role in the development of cerrado soil.

\section{Acknowledgements}

FAPESP (Proc. No. 2017/14168-1) and CNPq (INCT Proc. No. 465571/2014-0) in Brazil are thanked for financial support of this investigation.

\section{References}

Barbiero, L., Mohan-Kumar, M.S., Violette, A., Oliva, P., Braun, J.J., Kumar, C., Furian, S., Babic, M., Riotte, J., Valles, V., 2010. Ferrolysis induced soil transformation by natural drainage in Vertisols of sub-humid South India. Geoderma 156, 173-188.

Bonotto, D.M., Jimenez-Rueda, J.R., 2007. U-ages in soils and groundwater evidencing wet periods 400-600 kyr agoin southeast Brazil. Appl. Radiat. Isot. 65, 776-783.

Bonotto, D.M., Rueda, J.R.J., Fagundes, I.C., Fonseca Filho, C.R.A., 2017. Weathering processes and dating of soil profiles from São Paulo State, Brazil, by U-isotopes disequilibria. Appl. Radiat. Isot. 119, 6-15.

Bottinelli, N., Jouquet, P., Capowiez, Y., Podwojewski, P., Grimaldi, M., Peng, X., 2015. Why is the influence of soil macrofauna on soil structure only considered by soil ecologists? Soil Till. Res. 146, 118-124.

Chabaux, F., Dequincey, O., Levesque, J.J., Leprun, J.C., Clauer, N., Riotte, J., Paquet, H., 2003. Tracing and datingrecent chemical transfers in weathering profiles by trace element geochemistry and ${ }^{238} \mathrm{U}_{-}{ }^{234} \mathrm{U}_{-}{ }^{230}$ Th disequilibria: theexample of the Kaya lateritic toposequence (Burkina-Faso). CR Geosci. 335, 1219-1231.

Chabaux, F., Pelt, E., Lucas, Y., Allard, T., Fritsch, E., Balan, E., Selo, M., 2006. ${ }^{238} \mathrm{U}_{-}^{234} \mathrm{U}-{ }^{230} \mathrm{Th}-{ }^{226} \mathrm{Ra}$ radioactive disequilibria in an Amazon lateritic profile (Manaus, Brazil). Geochim. Cosmochim. Acta 70 (S1), A93.

Cherdyntsev, V.V., 1971. Uranium-234. IPST-Israel Program for Scientific Translations, Jerusalem.

Currie, L.A., 1968. Limits for qualitative detection and quantitative determination. Anal. Chem. 40 (3), 586-593.

Dodge, C.J., Francis, A.J., Gillow, J.B., Halada, G.P., Eng, C., Clayton, C.R., 2002 Association of uranium with ironoxides typically formed on corroding steel surfaces. Environ. Sci. Technol. 36, 3504-3511.

FAO - Food and Agriculture Organization of the United Nations, 2006. Guidelines for Soil Descriptions, 4th edition, Rome.

Fernandes, L.A., 2004. Mapa litoestratigráfico da parte oriental da Bacia Bauru (PR, SP, MG), Escala 1:1.000.000. Bol. Parana. 55, 53-66.

Fleischer, R.L., 1975. On the dissolution of respirable $\mathrm{PuO}_{2}$ particles. Health Phys. 29, 69-73.

IUSS Working Group WRB, 2014. World Reference Base for Soil Resources 2014: International Soil Classification System for Naming Soils and Creating Legends for Soil Maps. World Soil Resources Reports. 106 Food and Agriculture Organization of the United Nations, Rome.

Kigoshi, K., 1971. Alpha-recoil ${ }^{234}$ Th: dissolution into water and the ${ }^{234} \mathrm{U} /{ }^{238} \mathrm{U}$ disequilibrium in nature. Science $173,47-48$.

Langmuir, D., 1978. Uranium solutionmineralequilibria at low temperatureswith applications to sedimentary oredeposits. Geochim. Cosmochim. Acta 42, 547-569.

Latham, A.G., Schwarcz, H.P., 1987. On the possibility of determining rates of removal of uranium from crystallineigneous rocks using U-series disequilibria-1: a U-leach model, and its applicability to whole-rock data. Appl. Geochem. 2, 55-65.

Lucas, Y., Chauvel, A., 1992. Soil formation in tropically weathered terrains. In: Butt, C.R.M., Zeegers, H. (Eds.), Handbook on Exploration Geochemistry: Regolith Exploration Geochemistry in Tropical and Subtropical Terrains. Elsevier, Amsterdan, pp. 57-77.

Marshall, T.A., Morris, K., Law, G.T.W., Livens, F.R., Mosselmans, J.F.W., Bots, P., Shaw, S., 2014. Incorporation of uranium into hematite during crystallization from ferrihydrite. Environ. Sci. Technol. 48, 3724-3731.

Melfi, A.J., 1997. Brazilian bauxite deposits: a review. In: Carvalho, A., Boulangé, B. Melfi, A.J., Lucas, Y. (Eds.), Brazilian Bauxites. USP-FAPESP-ORSTOM. São PauloParis, pp. 03-22.

Osmond, J.K., Cowart, J.B., 1976. The theory and uses of natural uranium isotopic variations in hydrology. At. Energy Rev. 14, 621-679.

Pauli, F.W., 1975. Heavy metal humates and their behavior against hydrogen sulfide. Soil Sci. 119 (1), 98-105.

Peterschimitt, E., Fristch, E., Rajot, J.L., Herbillon, A.J., 1996. Yellowing, bleaching and ferritisation processes in soil mantle of the Western Ghâts, South India. Geoderma 74, 235-253.

Ponce, V.M., Cunha, C.N., 1993. Vegetated earthmounds in tropical savannas of central Brazil: with special reference to the Pantanal do Mato Grosso. J. Biogeogr. 20, 219-225.

Romero-González, M.R., Cheng, T., Barnett, M.O., Roden, E.E., 2007. Surface complexation modeling of the effectsof phosphate on uranium (VI) adsorption. Radiochim. Acta 95, 251-259.

Rosolen, V., Lamotte, M., Boulet, R., Trichet, J., Rouer, O., Melfi, A.J., 2002. Genesis of a 
mottled horizon by Fe-depletion within a laterite cover in the Amazon Basin. CR Geosci. 334, 187-195.

Stubbs, J.E., Elbert, D.C., Veblen, D.R., Zhu, C., 2006. Electron microbeam investigation of uranium-contaminatedsoils from Oak Ridge, TN, USA. Environ. Sci. Technol. 40, 2108-2113.

Szalay, A., 1964. Cation exchange properties of humic acids and their importance in the geochemical enrichment of $\mathrm{UO}_{2}{ }^{2+}$ and other cations. Geochim. Cosmochim. Acta 28, 1605-1614.

Tardy, Y., 1993. Pétrologiedeslatérites et dessolstropicaux. Mason, Paris.

Vepraskas, M.J., 2004. Redoximorphic Features for Identifying Aquic Conditions.

Technical Bulletin 301 North Carolina Agricultural Research Service, Raleigh, USA. 